\title{
Some new observations on the Volvariella genus Speg. 1898
}

\author{
Ajana M., Ouabbou A., El kholfy S., Nmichi A, Ouazzani Touhami A., Benkirane R. et \\ Douira A.
}

Laboratoire de Botanique et de Protection des Plantes, Université Ibn Tofail, Faculté des Sciences, B.P. 133. Kénitra, Maroc

\begin{abstract}
Three fungal species of the Volvariella genus were described in this study. Volvariella bombycina and Volvaria speciosa were harvested at the level of the Mamora forest. V. media was collected from one garden grass in the city of Kenitra, this species is new to the Moroccan fungal flora.
\end{abstract}

Keywords- Morocco, Mamora, Volvariella, fungal flora.

\section{INTRODUCTION}

The Volvariella Speg genus includes about 50 species worldwide (Kirk et al., 2008). It has been positioned in the family of Amanitaceae (Lee et al., 1959), then in the Agaricaceae family (Lee, 1973). According to Kirk et al., 2008, the Volvariella genus belongs to the Pluteaceae family (Agaricales, Hymenomycetidae, Eubasidiomycetes, Basidiomycotina, Eumycota) (Kirk et al., 2008), but recent molecular research has challenged its monophyletic and taxonomic position into the Agaricales (Moncalvo et al., 2002, Matheny et al., 2006). Most species of Volvariella are characterized by a stape with a volva at the base, absence of ring, free and spaced lamellae and pink spores with a more or less thick wall (Imai, 1938; Singer, 1986; Kühner \& Romagnesi 1956; Courtecuisse et Duhem, 2000 and Roux, 2006). Monographic studies of this genus have been mainly used in Europe (Kühner \& Romagnesi 1956; Orton 1974, 1986; Boekhout 1990) north America (Shaffer 1957) and in Africa (Heinemann, 1975 and Pegler, 1977). Six species of Pluteaceae belonging to the Volvariella genus have been reported in the flora of the upper mushrooms of Morocco (Volvaria bombycina; Volvaria murinella; Volvaria parvula; Volvaria plumulosa; Volvaria pusilla; Volvaria speciosa) (Malençon \& Bertault, 1975).

In this work, three species of the Volvariella genus, encountered in the Mamora forest, were studied: Volvariella bombycina, V. speciosa and V. media.

\section{MATERIALS AND METHODS}

Surveys were carried out in the cork oak forest of Mamora (North-West of Morocco) between 2009 and 2014 allowed us to study the fungal flora of this region.
Specimens of the Volvariella Speg. genus were collected and returned to the laboratory. The macroscopic descriptions were based on morphological characters (Shape, color, size, appearance,...) as well as other particularities of the cap and stipe (odor, flavor,...). This study was supplemented by a microscopic description of the spores and sections in the hymenium, cuticle, flesh and stipe. The dimensions of spores, cystidia, basidia and sometimes sterigmata are measured within a large-field micrometric eyepiece $10 \times(18 \mathrm{~mm})$ scale of $10 \mathrm{~mm}$ divided into 100 graduations $(0.1 \mathrm{~mm})$. Microscopic observations were made using an optical microscope (magnification $\times 400$ ). The mounting liquid is tap water. The forms of the basidiospores are obtained from the calculation of the quotient of $\operatorname{Bas}(Q=L / l, L$ and 1 are respectively the length and the width of the spore in $\mu \mathrm{m}$ ) (Bas, 1969).

Identification of the species was carried out by consulting the references of Malençon and Bertault (1970), Courtecuisse and Duhem (2000) and Roux (2006).

\section{RESULTS}

Three species of the Volvariella genus have been described in this study (Volvariella bombycina, Volvaria speciosa and Volvariella media), of which Volvariella media is new for the fungal flora of Morocco.

Volvariella bombycina (Volvaria bombycina) (Schaeff.) P. Kumm. 1871.

Lignicolous species harvested on 02/03/2009 and $12 / 08 / 2014$ in the hollow trunks of Quercus suber in the forest of Mamora.

The cap $(9-12 \times 1 \mathrm{~cm})$ is fluffy, silky, convex to planoconvex and white to pinkish to pale yellowish (Figure 49, A and B). The flesh is thick in the center, thin at the edges and whitish. The margin is inflected. The stipe (7$13 \times 0.6-1 \mathrm{~cm}$ ) is central, cylindrical, solid, firm, almost glabrous, thick and whitish cream colored. The volva is broad, black and spotted with brown. The lamellae are tight, wide, free, uneven and white to pink darker as they age.

The basidia (20 x 8 microns) are calviformes, hyaline and tetrasporic. The sterigmata are 6 to $8 \mu \mathrm{m}$ (Figure 49, 
D). The basidiospores $(6.6-8.5 \times 4.5-5 \mu \mathrm{m})$ are elliptic and pink in color $(1.3<\mathrm{Q}<1.7)$. The pleurocystidia $(63 \mathrm{x}$ $10 \mu \mathrm{m}$ ) are fusiform and hyaline (Figure 1).

Volvaria speciosa (Volvopluteus gloiocephalus)(Fr.) P. Kumm. 1871

Lignicolous species harvested on 20/03/2009 and $08 / 12 / 2014$ on the living trunks of Quercus suber in the forest of Mamora.

The cap ( 8 to $13 \mathrm{~cm}$ ) is parabolic then flared raised center with a rounded nipple and color: yellowish gray, pale yellow to white. The flesh is thin, elastic and concolorated to the cap. The margin is somewhat inflected. The stipe $(19.5-20 \times 1.5-2 \mathrm{~cm})$ is robust, flared under the gills, full, calviform towards the base and white or cream colored. The volva is short, fairly firm and whitish. The lamellae are tight, free, uneven and white and then pink to the pink-ocher end.

The basidia ( $40 \times 13$ microns) are calviformes subhymenium very long, hyaline and tetrasporic. The sterigmata are $3.3 \mu \mathrm{m}$ (Figure 50, C). The basidiospores $(8-10 \times \quad 4.5-5 \mu \mathrm{m})$ are elliptic $(1.3<\mathrm{Q}<1.7)$, amygdaliform, smooth and pink (Figure 50, D). The pleurocystidia $(103 \times 45 \mu \mathrm{m})$ are piriform to base more or less stretched and topped with a digiform expansion (Figure 2).

Volvariella media (Volvaria media) (Schumach.) Gillet 1876

The species was collected on 28-08-2013 from one garden grass of Stenotaphrum secundatum in the city of Kenitra.

The cap (4 to $6.5 \mathrm{~cm}$ ) is parabolic then flattened (depressed), circular, smooth, viscous and creamy white. The flesh is thick in the center, thins towards the margin and is whitish in color. The margin is straight and striated. The stipe $(8-9.5-20 \times 0.5-0.6 \mathrm{~cm})$ is cylindrical, solid, central, striped, glabrous, bulbous and white or cream colored. The volva is thin, fairly firm and whitish (Figure 51, C). The lamellae are loose, free, uneven and white in color and then pink to pink-briquetted. The lamellar edge is regular and whitish. The basidia $(63.3 \mathrm{x}$ 13.3 microns) are calviformes, sub-hymenium very long, hyaline and tetrasporic. The sterigmata are $4.5 \mu \mathrm{m}$. The basidiospores $(11.6-13.3 \times 8.5-10 \mu \mathrm{m})$ are elliptic $(1.3<\mathrm{Q}$ <1.7), amygdaliform, smooth and pink. The pleurocystidia $(76.6 \times 13.3 \mu \mathrm{m})$ are cylindrical and hyaline (Figure 3).

\section{DISCUSSION}

The Volvaria Fries (1821) genus is antedated by Volvaria de Candolle (1805), who designates a lichen, some modern authors substitute for it Volvariella Speggazini (1899), which has priority over Volvariopsis Murrill (1911) (Malençon and Bertault, 1970).
In Morocco six species of the genus Volvaria were encountered by Malençon and Bertault (1970), five of which are described (Volvaria bombycina (Schaeff.) Singer (1951), V. murinella Quél. (1883), V. parvula (Weinm.) P. Kumm. (1871), V. pusilla var. biloba Massee, ss. J. Lange et V. speciosa (Fr.) P. Kumm. (1871) and Volvaria plumulosa Lasch ex Quél. (1878), reported without specifying the substrate and the place.

Volvaria gloiocephala (DC.) Gillet (1876), was encountered in the forest of the Mamora (El Assfouri, 2006), near to the central plateau (Haimed, 2007) and under Quercus rotundifolia in the Middle Atlas (Larouz, 2007) and V. gloiocephala var. speciosa in the gardens of Kenitra (forest of the Mamora) (El Assfouri, 2006).

Volvaria bombycina was first described in 1774 by the German naturalist Jacob Christian Schäffer as Agaricus bombycinus. Throughout its taxonomic history, it has been redesigned to several genera, including Pluteus (Fries, 1836), Volvaria (Kummer, 1871) and Volvariopsis (Murrill, 1911). Whereas in 1951, it was placed in its current type Volvariella (Singer, 1951). This species is considered a rare and isolated generally believed mostly in autumn and winter. It occurs on Quercus suber and sometimes on Quercus faginea and on Populus (Malençon et Bertault, 1970). It has been reported in Europe, Africa, Asia, North and South America and Australia (Justo et al., 2011) and prefers low and high altitudes (Heinmann 1975). However, this species is considered a very important edible mushroom with chemical and nutritional characteristics (Mallavadhani et al., 2006), and has antioxidant, anti-tumor and hyporcholesterolemic effects (Badalyan \& Suzanna, 2003). Jegardeesh et al. (2010) reported V. bombycina as an ideal edible food for health by its richness in protein and mineral salts and it contains dietary fiber that allows good digestion. This mushroom has chemical compounds that can be used as antibacterial agents in new medicines for infectious disease therapy caused by pathogens (Jegardeesh et al.,2010).

Volvaria speciosa, is an edible species, has long been considered poisonous by confusion with Amanita phalloides Secr. 1833 (Malençon and Bertault, 1970). Otherwise, Volvariella gloiocephala and V. Speciosa are currently considered to be co specified (Orton, 1974, Boekhout and Enderle, 1986; Boekhout, 1990). Volvariella gloiocephala was created from V. speciosa mainly by its grayish brown cap, while that of $V$. speciosa is whitish (Shaffer, 1957; Coutecuisse, 1984). However, the original description does not provide any arguments for this distinction since De Candolle (1815) described the cap of Agaricus gloiocephalus (DC.) like a gray white mouse, while Fries (1818) described the cap of Amanita speciosa (Fr.) like a white to gray center 
(Boekhout \& Enderle, 1996). In addition, the two colorations were experimentally obtained from the same mycelium (Herrmann, 1973).

Volvariella media (Schum.: Fr.) Singer ss. Quélet, is characterized by a cap of 3 to $6 \mathrm{~cm}$ in diameter, ivory, and whitish, a stipe $(3-6 \mathrm{~cm})$ with wholly volva and spores 11 to $16 \mu \mathrm{m}$ in length and 7 to $8 \mu \mathrm{m}$ in width. This species resembles Volvariella gloiocephala, but it is only a smaller and more slender form that develops on poor substrates (Orton, 1986; Gerault, 2005). However, Larouz (2007) and Haimed (2007) described Volvariella gloiocephala, but with macroscopic and microscopic characteristics that are very distinct from those observed in Volvariella media. To cope with these different characteristics, we have drawn up a comparative table between the descriptions of Volvariella gloiocephala described by Larouz (2007) and Haimed (2007) and those of Volvariella media presented in this study (Tableau 1).

Similarly Volvariella media has been described under the name of Agaricus medius (Schumacher, 1803). This species is very close to Agarcicus speciosus, but is distinguished by a small white cap and free lamellae (Fries, 1821; Lange, 1935-1940).

Table.1: Comparison between Volvariella gloiocephala described by Larouz (2007) and Haimed (2007) and Volvariella media and Volvariella gloiocephala described in this study.

\begin{tabular}{|l|l|l|l|}
\hline Cap & $\begin{array}{l}\text { Volvariella gloiocepala } \\
\text { described by Larouz }(2007)\end{array}$ & $\begin{array}{l}\text { Volvariella gloiocepala } \\
\text { described by Haimed }(2007)\end{array}$ & $\begin{array}{l}\text { Volvariella media } \\
\text { described in this study }\end{array}$ \\
\hline $\begin{array}{l}(9 \mathrm{~cm}) \text { greyish white, ovoid } \\
\text { becomes campanulate then } \\
\text { spreads out with age } \\
\text { keeping a central nipple. }\end{array}$ & $\begin{array}{l}\text { (6 to } 11 \mathrm{~cm}) \text { campanulate, } \\
\text { yellow and gray to pinkish } \\
\text { state with age, often hilly, } \\
\text { viscous and furrowed } \\
\text { margin short streaks }\end{array}$ & $\begin{array}{l}\text { (4 to 6.5 cm), parabolic and then } \\
\text { flattened (depressed), circular, } \\
\text { smooth, viscous and creamy } \\
\text { white. }\end{array}$ \\
\hline Stipe & $\begin{array}{l}(7 \times 1 \mathrm{~cm}) \text { is white, firm and } \\
\text { cylindrical thickening } \\
\text { towards the base enclosed in } \\
\text { a volva. }\end{array}$ & $\begin{array}{l}(11-17 \times 1.5 \mathrm{~cm}) \\
\text { cylindrical, glabrous, } \\
\text { whitish to light fawn to } \\
\text { ample volva. }\end{array}$ & $\begin{array}{l}\text { (8-9.5-20 x 0.5-0.6 cm) is } \\
\text { cylindrical, solid, central, striped, } \\
\text { glabrous, bulbous and of white } \\
\text { color or cream with thin volva, } \\
\text { fairly firm and whitish. }\end{array}$ \\
\hline Lamellae & $\begin{array}{l}\text { Free, fine, tight and white } \\
\text { become pinkish at maturity. }\end{array}$ & $\begin{array}{l}\text { Free, broad, clenched at first } \\
\text { white and then pinkish. }\end{array}$ & $\begin{array}{l}\text { Little tight, free, uneven and } \\
\text { white in color and then pink to } \\
\text { pink-briquetted. }\end{array}$ \\
\hline Basidia & Clave and tetrasporic. & $\begin{array}{l}\text { Claviform, sub-hymenium, } \\
\text { hyaline and tetrasporic. }\end{array}$ \\
\hline cystidia & In bulbs & $\begin{array}{l}\text { (76.6 x 13.3 } \mu \mathrm{m}) \text { are cylindrical } \\
\text { and hyaline. }\end{array}$ \\
\hline Basidiospres & $16.6-18.3 \times 6.7-8.3 \mu \mathrm{m}$. & $\begin{array}{l}11.6-13.3 \times 8.5-10 \mu \mathrm{m}) \text { are } \\
\text { elliptical. }\end{array}$ \\
\hline
\end{tabular}

\section{CONCLUSION}

In this study, three species (Volvariella bombycina, $V$. speciosa and V. media) belong to the Volvariella genus, two of which (Volvariella bombycina, V. speciosa) have already been reported and described in Morocco by Malençon and Bertault (1970), El-Assfouri (2006), Haimed (2007) and Larouz (2007), while Volvariella media is newly described for the fungal flora of Morocco. However, a comparison between the latter species and Volvariella glioicephala allowed us to confirm the nomenclature of Volvariella media.

\section{REFERENCES}

[1] El-Assfouri A., 2006. Biodiversité fongique du Maroc : Inventaires et étude des Basidiomycètes de la forêt de la Mamora. Thèse de Doctorat, Université
Ibn Tofaïl, Faculté des Sciences, Kénitra, Maroc, 294p.

[2] Badalyan and Suzanna M., 2003. Edible and medicinal Higher Basidiomycetes mushrooms as a source of natural antioxidants. Intl. J. Med. Mushrooms, 5: 153-162.

[3] Bas C., 1969. Morphology and subdivision of Amanita and a monograph on its section Lepidella, Persoonia, 5 (4): 285-579.

[4] Boekhout T. \& Enderle M., 1986. Volvariella gloiocephala (DC.; FR.) Boekhout \& Enderle comb. Nov. Beitr. Kenntn. Plize Mitteleur, 2: 77-80.

[5] Boekhout T. 1990. Volvariella, in C Bas, ThW Kuyper, ME Noordeloos, EC Vellinga (eds.). Flora Agaricina Neerlandica 2. Rotterdam, A.A. Balkema. 56-64. 
[6] Courtecuisse R., 1984. Notes de reconnaissance macroscopique des principales espèces de champignons du nord de la France IV : le genre Volvariella Spegazzi,i. Bull. Soc. Mycol. Nord Fr. 34: 14-25.

[7] Courtecuisse R. and Duhem B., 2000. Guide des champignons de France et d'Europe. Ed. Delachaux et Niestlé, S. A. Lausane (Switzerlande), Paris, 476 p.

[8] De Candolle A. P., 1815. Flore française, vol. 6, Paris.

[9] Fries E.M., 1818. Observationes mycoloficae, Havniae, vol.2, 272p.

[10] Gerault, A. 2005. Florule evolutive des Basidiomycotina $\mathrm{du} \quad$ Finistere, (Homobasidiomycetes, Agaricales), Version 2.1. $183 \mathrm{p}$.

[11] Haimed M., 2007. Biodiversité fongique du Maroc: Etude des champignons Basidiomycètes du Plateau Central et des Jardins Exotiques. Thèse de Doctorat, Univ. Ibn Tofail, Fac. Sci. Kénitra, Maroc, 265 p.

[12] Heinemann P., 1975. Flore Illustrèe des champignons d'Afrique centrale 4: Volvariella. Meise, National Botanical Garden of Belgium. 7384.

[13] Herrmann M., 1973. Die farbnuancen des Ansehnlichen Scheidlings. Mykol. Mittbl. 17: 19-20.

[14] Imai S., 1983. Studies on the Agaricaceae of Hokkaido. Jour. Facul. Agr. Hokkaido Imp. Univ. Sapporo, Vol. XLIII, Pt. 1. 178 p.

[15] Jagadeesh R., Raaman N., Periyasamy K., Hariprasath L., Thangaraj R., Srikumar R. and Ayyappam S.R., 2010. Proximate analysis and antibacterial activity of an adible mushroom Volvariella Bombycina. Intertnational Journal of Microbiological Research, ISSN 2076-2093, 1 (3): 110-113.

[16] Justo A., Vizzini A., Minnis A.M., Menolli Jr. N., Capelari M., Rodriguez O., Malysheva E., Contu M., Ghingnone S., Hibbett D.S., 2011. Phylogeny of the Pluteaceae (Agaricales, Basidiomycota): taxonomy and character evolution. Fungal Biology, 115: $1-20$. http://dx.doi.org/10.1016/j.funbio.2010.09.012

[17] Kirk P.M., Cannon P.F., Minter D.W., Stalpers J.A,. 2008. Dictionary of the Fungi. 10th edn. CABI, Wallingford, UK.

[18] Kühner R., et Romagnesi H., 1956. Flore analytique des champignons supérieurs. Masson et Cie, Paris, $557 \mathrm{p}$.

[19] Lange J., (1935-1940). Flora agaricina Danica. Copenhagen. 106p
[20] Larouz B., 2007. Biodiversité fongique du Maroc: Etude des champignons supérieur du Moyen Atlas. Thèse de Doctorat, Université Ibn Tofaïl, Faculté des Sciences, Kénitra, Maroc. 332 p.

[21]Lee J.Y., Lee Y.W. and Lim J., 1959. Coloured Illustrations of Fungi of Korea, Baemunkak. Seoul.138 p.

[22] Lee, J. Y. 1973. The list of the fungi of Korea. Kor. J. Mycol. 1(1): 35-43.

[23] Malençon G. et Bertault R., 1970. Flore des champignons du Maroc, Tome I. Faculté des Sciences, Rabat,Maroc, 601 p.Maroc, 539 p.

[24] Mallavadhani U.V., Sudhakar A.V.S., Satyanarayans K.V.S., Mahapatra A., VanBreeman R.B., 2006. Chemical and analytical screening of some edible mushrooms. Food Chem., 95: 58-64.

[25] Matheny P. B. and Bougher N. L., 2006. The new genus Auritella from Africa and Australia (Inocybaceae, Agaricales): molecular systematics, taxonomy and historical biogeography. Mycol. Progress 5: 2-17.

[26] Métro A. \& Sauvage Ch., 1951. La nature au Maroc. Flore des végétaux ligneux de la Mamora. Marcel Bonvesoul, Casablanca, $224 \mathrm{p}$.

[27] Moncalvo J. M., Vilgalys R., Redhead S. A., Johnson J. E., James T. Y., Aime M. C., Hofstetter V., Verduin W., Larsson, E., Baroni T. J., Thorn R. G., Jacobsson, S., Clemençon, H. and Miller, O. K., 2002. One hundred and seventeen clades of euagarics. Molecular Phylogenet. Evol., 23: 357-400.

[28] Orton P.D. 1974. The European species of Volvariella. Bull. Soc. Linn. Lyon $\mathrm{N}^{\circ}$. special, 43: 313-326.

[29] Orton P.D., 1986. Pluteaceae: Pluteus \& Volvariella, in Henderson P.M., Orton P.D. and Watling R. (eds), British Fungus Flora: Agaricus and Boleti. , Royal Botanic Garden Edinbergh, 4: 1-98.

[30] Pegler DN. 1997. The agarics of São Paulo, Brazil. London, Royal Botanic Garden Kew. 68p.

[31] Roux P. 2006. Mille et un champignons. Éd. Roux: Sainte-Sigolène (France), $1223 \mathrm{p}$.

[32] Schumacher C.T., 1803. Enumeratio plantarum in partibus Saellandiae. Havniae, 883p.

[33] Shaffer R.L., 1957. Volavariella in North America, Mycologia, 49: 545-579.

[34] Singer R., 1951. "The Agaricales in Modern Taxonomy". Lilloa (2 ed.): 22: 401.

[35] Singer R., 1986. The Agaricales in Modern Taxonomy (4th Ed.). Königstein im Taunus, Germany: Koeltz Scientific Books, 981 p. 

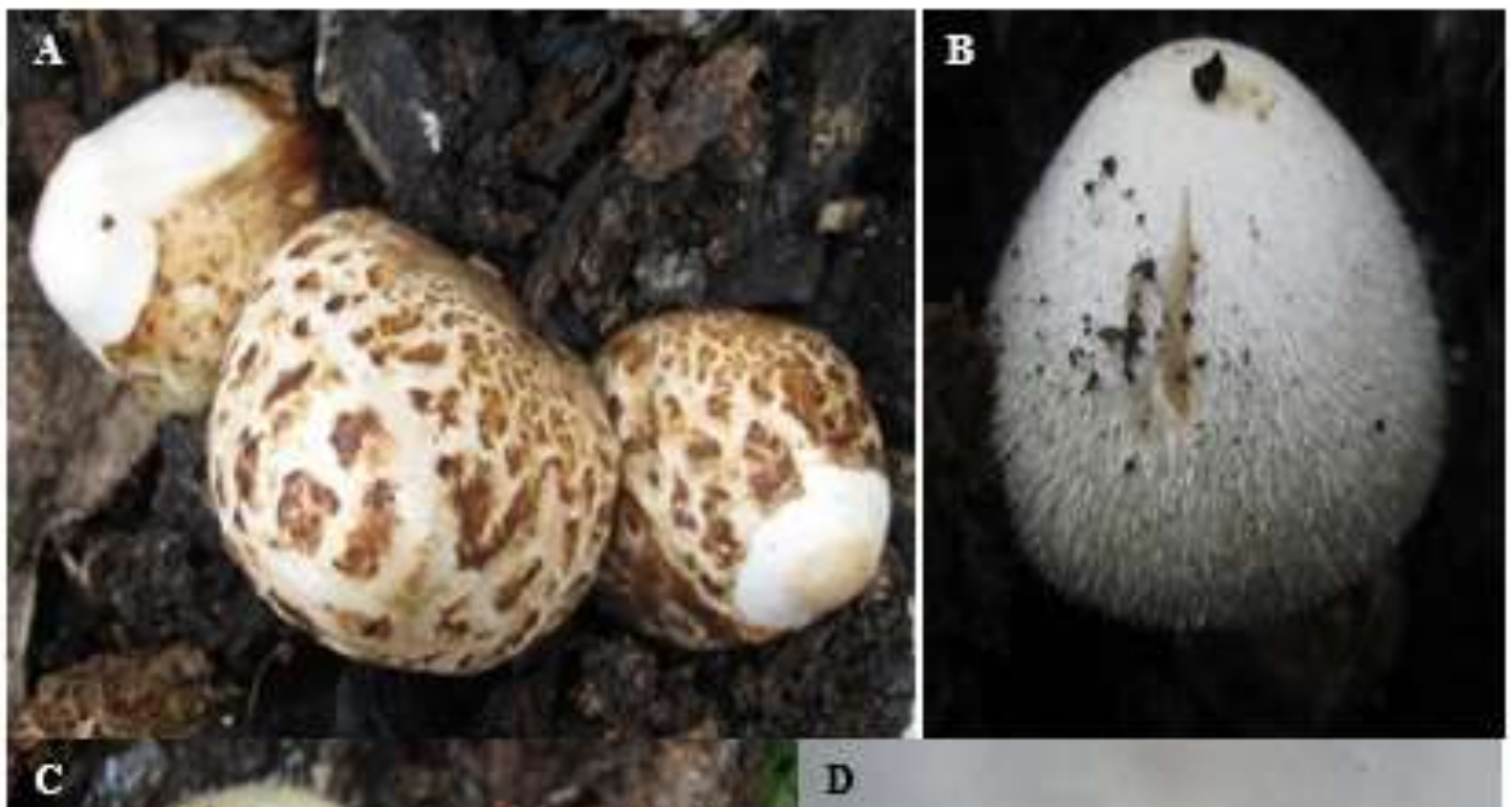

D
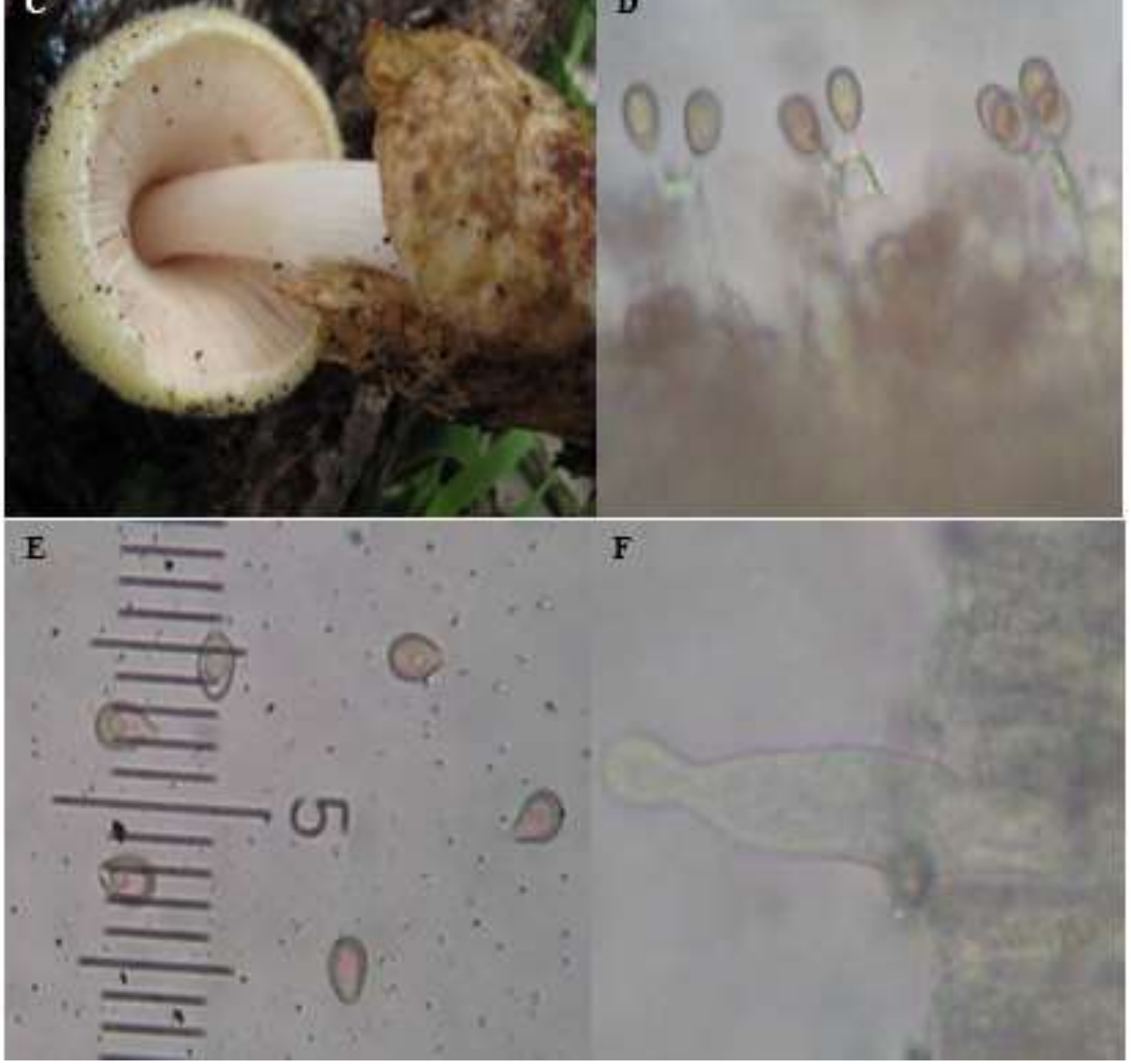

Fig.1: Surface of the cap (A) and (B) insertion of the lamellae, stipe and volva $(C)$, Basidia $(C$ and $D)$, basidiospores (E) and cheilocystidia $(F)$ of Volvaria bombycina $(\times 400)$. 


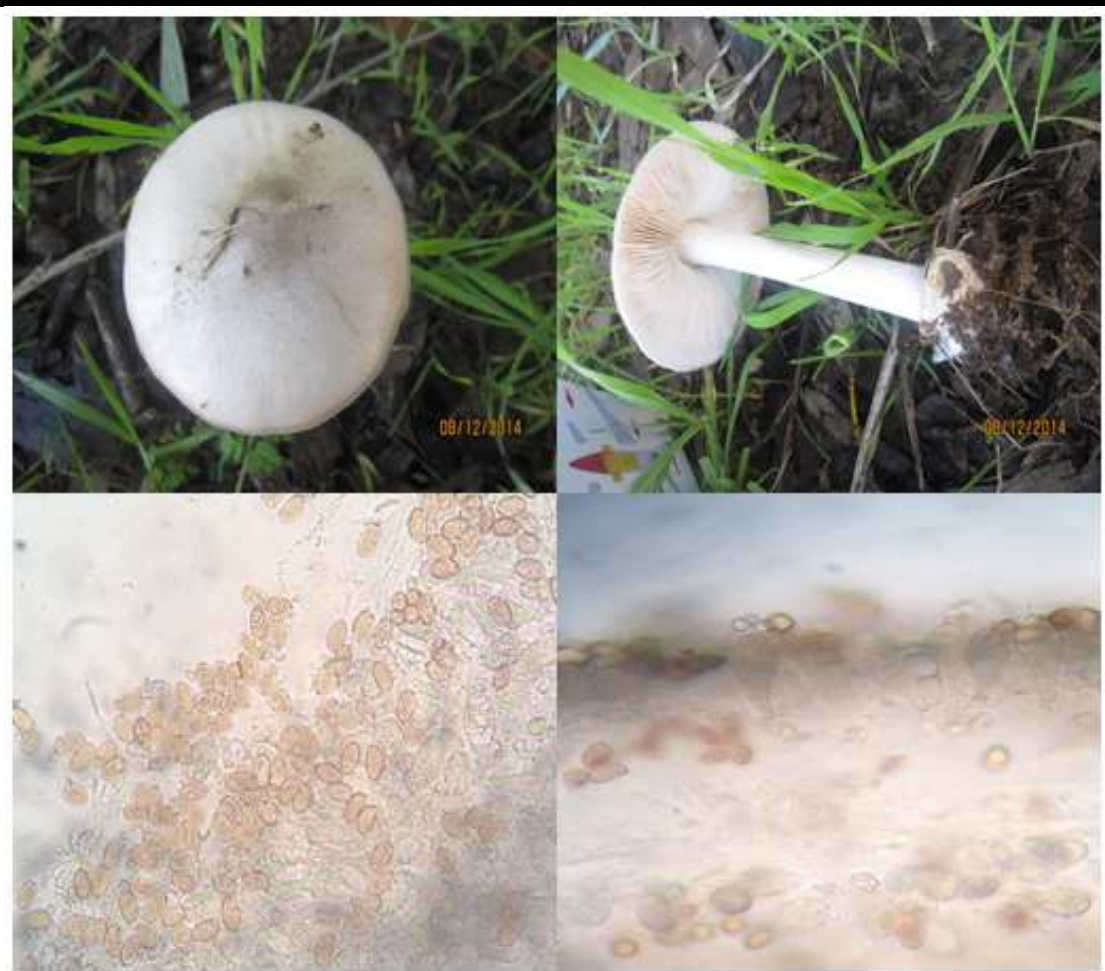

Fig.2: Cap surface (A) insertion of the lamellae, stipe and volva (B), Basidia (C), basidiospores (D) of Volvaria speciosa $(\times 400)$

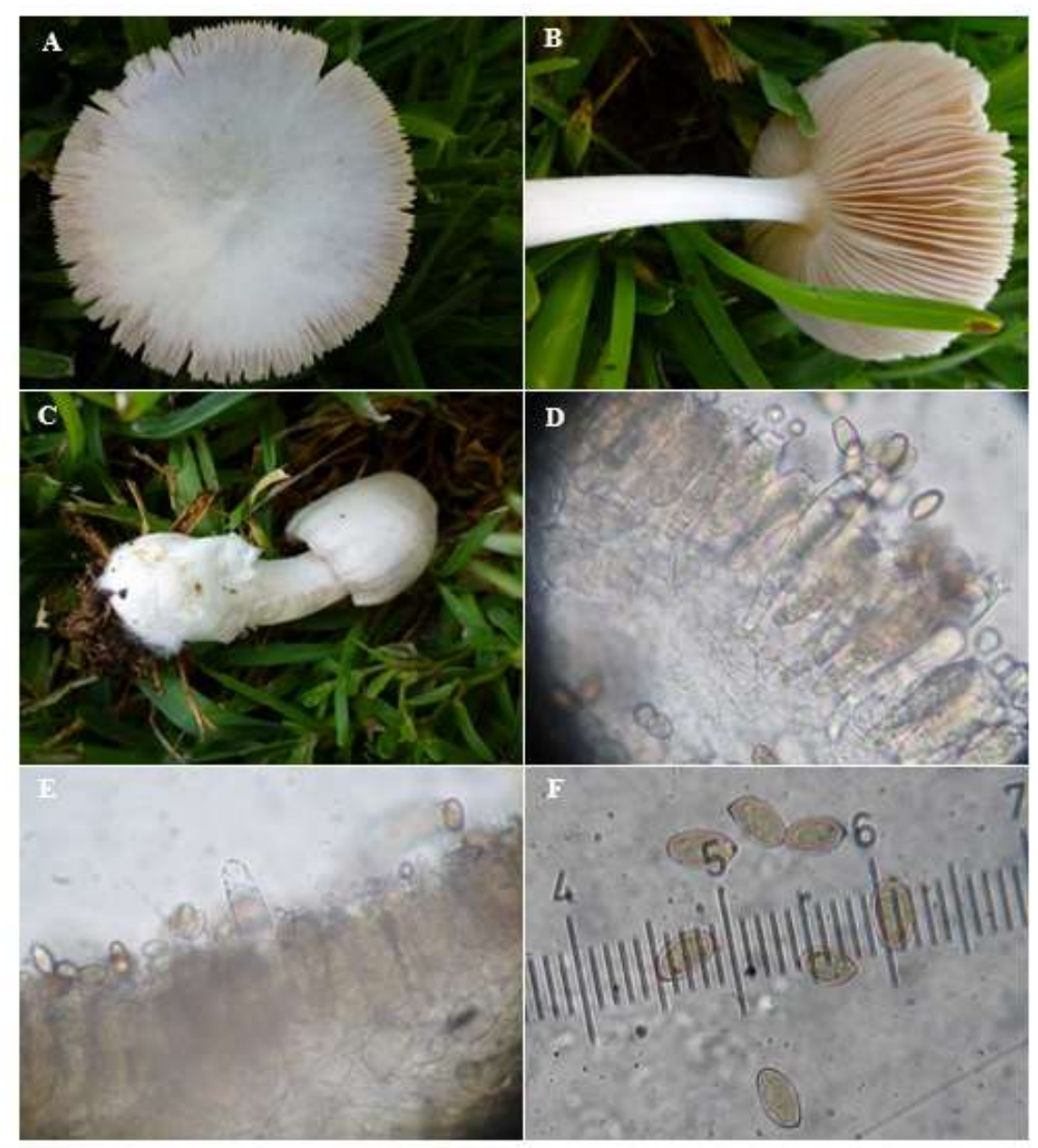

Fig. 3: Cap surface (A), (B) insertion of the lamellae and stipe $(B)$, volva $(C)$, basidia $(D)$, cheilocystidia $(E)$ and basidiospores $(F)$ of Volvaria media $(\times 400)$. 